\title{
The Classical Approaches to Testing the Unconditional CAPM: UK Evidence
}

\author{
Mehnaz Roushan Laura ${ }^{1} \&$ Nafiz U1 Fahad ${ }^{2}$ \\ ${ }^{1}$ Department of Accounting and Information System, Jahangirnagar University, Dhaka, Bangladesh \\ ${ }^{2}$ Department of Accounting and Finance, American International University-Bangladesh (AIUB), Dhaka, \\ Bangladesh \\ Correspondence: Nafiz Ul Fahad, Lecturer, Department of Accounting and Finance, Faculty of Business \\ Administration, American International University-Bangladesh (AIUB), Dhaka-1213, Bangladesh. Tel: \\ 88-0721-750711. E-mail: nafiz.ul.fahad@gmail.com
}

Received: January 15, 2017

Accepted: February 4, $2017 \quad$ Online Published: February 20, 2017

doi:10.5539/ijef.v9n3p220

URL: https://doi.org/10.5539/ijef.v9n3p220

\begin{abstract}
This empirical study attempts to test the unconditional capital asset pricing model. Two-pass regression models are employed using 86 randomly chosen companies of LSE during 1997 to 2015. A two stage approaches have been applied to investigate whether excess returns can be explained by the market risk. Based on empirical results of the first pass regression, among the 86 companies 81 companies are consistent with the prediction of CAPM except five companies. However, the estimated R-square of the sample companies are very low and indicate that market excess return has low explanatory power. In the second pass regression, empirical result shows that beta coefficient is negative and statistically significant which implies that rate of return has no linear positive relationship with beta. Further, coefficient of residual variance is also observed negative and statistically significant which violates the CAPM assumption as unsystematic risks are assumed to have no impact on rate of return. In conclusion, CAPM predictions are not consistent with the findings of this study; hence CAPM is violated and does not hold.
\end{abstract}

Keywords: CAPM, two-pass regression, systematic risk, unsystematic risk, beta, London stock exchange

\section{Introduction}

Since its origin, the Capital Asset Pricing Model (CAPM) has been criticized both theoretically and empirically more than it has been appreciated. Nevertheless, it is still one of the widely-used security pricing models. The groundwork for the development of various models of asset pricing were laid by Markowitz (1952) and Tobin (1958). Initial theories advocate that standard deviation is used as proxy for return volatility of individual security and higher standard deviation implies greater risk. Markowitz (1952) was the first to develop a theory that is not concerned with investment in a single asset rather it is a theory that describes how investors should construct a diversified portfolio of different assets. According to the 'Portfolio Selection Theory' of Markowitz, unsystematic risks can be diversified by constructing a diversified portfolio except systematic risk and the process consists of two stages. The first stage starts with plotting rates of return on different efficient portfolio against their risks on two-dimensional graph and the summarized curve is known as efficient frontier. The second stage is concerned with the selection of "mean-variance-efficient" portfolio from the efficient set. Tobin (1958) suggests an approach to determine the appropriate portfolio among the efficient set. Furthermore, he contributes to the Markowitz's portfolio theory by extending the concept of a risk-free asset and he also finds that utility-maximizing portfolio is a mix of risk-free asset and a portfolio contains risky assets. However, Markowitz's and Tobin's work of mean-variance behaviour is more theoretical and does not explain how return expectation of individual security should form by investors. Therefore, Markowitz model could not be considered as a theory of equilibrium prices in the capital market before Sharpe (1964) made it empirically testable.

CAPM was originally developed separately by Sharpe (1964), Lintner (1965) and Mossin (1966) based on the Markowitz's research (1952) on 'portfolio selection' theory. The CAPM is originally a model that attempts to explain equilibrium price of individual security under the condition of risk. According to the CAPM, for any individual asset or portfolio of assets, there is a linear relationship between expected excess return of that asset 
and the "systematic risk" of that asset. "Systematic risk" is known as non-diversifiable risks that is associated with overall movement in the general markets or in the economy and is often referred to as 'market risk'. The CAPM is also referred to as single factor model as it is based on the supposition that required rate of return on individual asset can be predicted using one factor, i.e. 'market risk'. Since unsystematic or firm specific risk is diversified away, hence investors should only get compensation or risk premium for systematic risk as argued by Sharpe (1964). Development of CAPM is based on some key assumptions as specified by Sharpe (1964) and Linter (1965). However, these assumptions are derived from and are modified extension of Markowitz portfolio selection model.

The motivation behind this empirical research is to inspect whether security return can be described by CAPM using real market data. Earlier empirical studies of the CAPM such as those by Lintner (1965), Black et al. (1972), Miller and Scholes (1972), Fama and MacBeth (1974) and Levy (1978) have applied to test the linear positive relationship between rate of return and systematic risk (beta) for cross sectional security. However, these early studies found some empirical evidence to support that there is a positive significant relationship, albeit these results are mixed and CAPM performed poorly in these tests. Based on the two-pass regression approach, first-pass regression (time series) attempts to examine the validity of CAPM based on the assumption of zero intercept for every asset. The second-pass regression (cross-sectional) investigates whether the rate of return has linear positive relationship with systematic risk (stock beta). Further, it is also examined whether beta is the only variable that affect the expected excess return and not by any other unsystematic factors.

\section{Review of Related Literature}

The first cycle of these empirical studies reveals some empirical support for the CAPM. Earlier empirical studies of Lintner (1965) and Douglas (1969) are initially based on returns of individual security and their results were discouraging. Lintner (1965) was the first to conduct the comprehensive empirical test of CAPM based on two pass-regression model using 301 stocks with the annual rate of return covering the period 1954-1963. The encouraging result is that the sample beta and the average return have a positive and significant relation. But the discouraging fact is that the coefficients are significantly different from what was predicted by the CAPM. Hence, there is a deviation between the CAPM (or the theoretical line) and the empirical result (or empirical line).

Miller and Scholes (1972) replicate the Lintner's study covering the same period and extend their study by employing a larger sample. The results of their study are very similar to the results obtained by Lintner except the residual variance itself explains $28 \%$ of the variation in mean return (where beta and residual variance jointly explain 33\%). However, they encounter some statistical problems while using the individual securities and highlighted some possible reasons for the observed biases in the results of second pass-regression. Miller and Scholes (1972) analyse the influence of various statistical measurement errors while obtaining estimated beta from first pass-regressions. Conducting some statistical analysis, they conclude that using these estimated betas instead of true beta coefficient generate biases in the estimation of second pass-regression. Furthermore, it also led to a too flat (SML) with a positive rather zero intercept.

Consequently, the following studies are designed to solve the measurement error and biases in beta estimation by using portfolio return. Black et al. (1972) come up with a smart approach while testing the validity of CAPM with monthly data corresponding to the period 1926-1966. To reduce the errors in beta estimation, they set all stocks into ten portfolios with very different betas for empirical tests. Black et al. (1972) test both CAPM and zero beta models as they want to study whether the results are consistent across various sub periods since they cover a very long period. Black (1972) develops an equilibrium model based on relaxing the riskless borrowing and lending assumption. However, the investigation of Black et al. (1972) shows strong relation between average return and beta in cross-sectional regression and unlike previous studies they find a high R-square value of $98 \%$ indicating the high explanatory power in explaining the variation of the mean-returns. Even though beta has high explanatory power, Black et al. (1972) reject the CAPM as the intercept and the slope of the regression have the systematic deviation from what is predicted by CAPM. One plausible explanation for the deviation in strict CAPM is the absence of risk-free borrowing and lending as argued by Black (1972). Hence, they suggest employing Black's (1972) zero beta model for better empirical results. Furthermore, Black et al. (1972) do not examine other implication of CAPM, such as whether the expected return and beta has linear relation or expected returns are independent of unsystematic risk.

To address the shortcoming of Black et al. (1972) test, Fama and MacBeth (1973) employ a slightly different methodology and construct twenty portfolios using return data of New York Stock Exchange (NYSE) covering the period 1926-1968. To substantiate that unsystematic risks, have no significant impact in portfolio's excess 
return, they expand the equation by including the squared value of beta and estimated standard deviation of the residual term. Unlike previous studies, this study supports the CAPM and provides evidence of (1) a greater intercept value than risk-free rate, (2) non-systematic risks have no significant impact on portfolio's excess return, (3) linear positive relation between return and beta holds. However, their finding suggests that calculated (SML) is still too flat to examine the theoretical SML. Early empirical studies certainly provide some evidence regarding the beta as a measure of risk but still not an ideal proxy. Nonetheless, in some subsequent studies including Levy (1978) provide some proof that the residual variance acts as an important variable in describing the variation of mean returns across assets.

The second cycle of the research is based on an increasing number of studies indicated that market beta alone may not be enough to interpret the cross-sectional variation in security returns rather other fundamental variables should be tested. Empirically it has been found that firm with a small capitalisation (small cap) tend to gain positive abnormal average returns than large firms. Banz (1981) inspects the CAPM model by investigating whether the residual variation in the return can be described by size effect since beta of CAPM alone fails to explain it. Banz employs a procedure like Black et al. (1972) using monthly returns covering the period 1926-1975 of all stock listed on the NYSE. Further, he divides the whole period studies into sub-periods and measures the cross-sectional relationship between corresponding returns, their betas and relative size factor. $\mathrm{He}$ finds a negative relationship between size and return as the small firm earned subsequently higher abnormal return than the larger firms during the period 1936-1975 which is not explained by the CAPM. Based on his result Banz disputes the validity of the CAPM by showing that size does interpret cross-sectional variation in security return better than beta as pointed out by Jagannathan and McGrattan (1995). Simultaneously, another article was published by Reinganum (1981) which also inspects the small firm effect. He examines empirically the various anomalies that dispute the CAPM. Specifically, he finds that the CAPM is inconsistent when portfolios returns are classified either by price/earnings $(\mathrm{P} / \mathrm{E})$ ratio or by size. He also concludes that either the CAPM is misclassified or the market is not efficient.

Basu (1977) who puts an argument in the P/E anomaly also finds that after accounting for beta, lower P/E ratio incorporates with the higher abnormal return as well as lower market size of the firm also incorporates with greater abnormal return. Thus, show some consistency with Banz (1981) and Reinganum (1981) findings'. Later Basu (1983) shows that cross-section average returns on the U.S. stocks can also be explained by earnings-price ratios $(\mathrm{E} / \mathrm{P})$ where they also include size and market beta. Moreover, Stattman (1980) detects that returns and ratio of book-to-market (BE/ME) value have significant association on the U.S. stocks and in response to their findings Rosenberg et al. (1985) also find the same result. Later, Chan et al. (1991) find the same results on the Japanese market. However, Bhandari (1988) states that average return and leverage also have positive association and point it as conflict to the CAPM model.

Since the CAPM is derives under a set of restrictive assumptions, Merton (1973) suggests an equilibrium model by relaxing the assumption of static single period holding. Under the single period holding assumption, the CAPM presume that investors will select a portfolio at the beginning, anticipate for time to pass and uncertainty to adjust, and at the end of period liquidate the portfolio. Merton's (1973) intertemporal capital asset pricing model (ICAPM) is a model that attempts to capture this multi-period effect of financial market equilibrium and surmise that asset returns are log normally distributed. As the single period model fails to describe that the return distribution (mean-variance efficient frontier) changes over time due to change in the state of economy and investors adjust their portfolio accordingly. It also assumes that investors seek to maximize their expected utility at each time for lifetime consumption. Basically, the ICAPM examines how investors could determine a portfolio that is dynamically optimal over the investor's entire investment horizon, rather not just for one period. Thus, ICAPM is a continuous consumption investment model that allows non-stable future efficient set at any given time. Merton (1973) posits that the risk factors that explain the cross-section variation of security returns have to be associated with the market return, innovations in the state of variables that predicts the stochastic variation in investment opportunities. To develop a simplest form of model, Merton assumes that if risk-free interest rate is non-stochastic (constant) then the investment opportunity set is also consistent. Unfortunately, this assumption is not consistent with the facts because at least one state variable is directly observable from the opportunity set, such as interest rate as it changes over time. Thus, ICAPM does not consider the risk factors from any set of factors that are correlated with return, rather the innovative state variable that forecast future returns.

Surprisingly, despite the evidence of stock return predictability and time variation in investment opportunities, comparatively a little effort was made to test the ICAPM framework. One of the reasons behind is the tendency to merge the Ross's (1976) arbitrage pricing model and ICAPM jointly and put them under the same heading of 'Factor Pricing Model' as noted by Brennan, Wang and Xia (2004). Thus, the distinguishing characteristic of 
ICAPM is ignored. Further, ICAPM does not explicitly tell the identity of state variables and lead to the 'fishing licence' criticism as labelled by Fama (1991). Since the selected level of consumption endogenously indicated the various hedging-demand impacts of ICAPM, Breeden (1979) argues that Merton's (1973) ICAPM is identical to a single beta consumption model. Similar to the ICAPM and Breeden's (1979) consumption based CAPM, arbitrage pricing theory (APT) model developed by Ross (1976), is also considered as an alternative model. The basic idea behind the APT is to include more than one measure of systematic risk. Based on the different set of assumptions, APT does not assume investors as risk averse or mean variance optimizer. Rather, he argues that absence of arbitrage opportunities in security market produce the linear association between risk and return. Thus, it is based on 'the law of one price' and this is the core difference between APT and CAPM in the explanation of equilibrium asset prices. In addition to that under the no-arbitrage condition of APT, Cochrane (2001) states that even comparatively small number of investors are enough to recognize an arbitrage opportunity and employ pressure on the price to restore equilibrium.

Under the assumptions of APT, short sales are permitted and gains are transferred to the investors. Further, Ross (1976) employs the argument of zero investment to derive APT and conclude that the future returns on the portfolio are non-negative. However, Unlike CAPM that employs unobservable market portfolio as the only source of all systematic risk of securities, APT postulates that systematic risk for all securities could be obtained from any number of macroeconomic factors. Thus, any index that the CAPM exerts as a substitute for market portfolio can be employed to APT model as one of the appropriate factors even if the index is not a mean-variance efficient portfolio. In this way, the APT model overcomes the major problem of finding suitable proxy for market portfolio as affected by CAPM. Moreover, since each security has different response to different macroeconomic factors and APT model incorporates these different responses by defining distinct beta coefficient with regards to every common factor for each security. Later studies of Chen et al. (1986) and Roll and Ross (1984) identified four economic variables: inflation, default risk premium, industrial production and term premium that influence the future cash flow. Groenewold and Fraser (1997) conduct a comparative empirical study to test the validity of the APT and CAPM for Australian data and conclude that in terms of explanatory power, APT outperforms the CAPM. Thus, APT is based on fewer but more realistic assumptions which can be applied in both the single and multi-period settings. But empirically APT is difficult to assess since it does not state the specification or the number of factors to be included in the model.

Subsequent tests of CAPM follow two distinct lines of thinking as indicated by Sharifzadeh (2010). The first line of thinking is pioneered by Fama and French (1992) who publishe the highly-cited paper that is probably most critical about the validity of the CAPM. They attempt to determine other factors in addition to the CAPM beta to test whether they can explain the variation of return in cross section of stocks. They develop a three-factor model based on the identical procedure that applied by Fama and MacBeth (1973). They test the model by regressing the rate of return on various combinations of explanatory variables using monthly data listed in NYSE, AMEX and NASDAQ for the sample period 1963-1990. The explanatory variables are beta ( $\beta$ ), non-market risk factors including size (as measured by the market capitalization), earning to price ratio $(\mathrm{E} / \mathrm{P})$, ratio of equity book value to its market value (BE/ME) and two leverage variables. Their findings provide a strong evidence against the suppositions of CAPM as beta alone has no power to explain the cross-sectional difference in average returns and the connection between average return and beta is flat. They find that (BE/ME) and size have strong influence of the cross-sectional differences on average stock returns for the period 1963-1990. Further, the study suggests that among the two influential variables, (BE/ME) appears to be more influential than size. Surprisingly, these results contrast with the early study by Fama and MacBeth (1973) which shows a positive connection between return and beta where the study of Fama and French (1992) detects no association at all. The plausible explanation suggested by the authors for the dissimilarity in the results is that these two studies correspond to two different time periods. Finally, they conclude that (BE/ME) and size are crucial variables and should replace beta altogether. Later in their following article published in 1995, they claim that three factor model has more capacity to capture the main explanation for return variability across assets.

While Fama and French (1992) have presented impressive evidence against the validity of CAPM, Jagannathan and Wang (1993) state that the results of previous studies of the CAPM's death are somehow mixed and exaggerated. However, annual and monthly data do not produce the same estimated result for beta as argued by Levhari and Levy (1977). In response to the findings of Fama and French (1992), Kothari et al. (1995) recommend that the use of annual returns may provide better support in favour of CAPM beta. Further, they find high standard error for beta coefficient estimates and suggest that the beta is too noisy to disprove the CAPM which is also supported by Amihud, Christensen and Mendelson (1992) and Black (1993). Based on the analysis of Fama and French (1992), Black (1993) suggests that the size impact as documented by Banz (1981) might be 
the result of sample period effect and empirical studies include size for some period and not in others. Later, Horowitz et al. (2000) argue that size impact may have vanished since 1982 and suggest possible explanation as the size impact is not strong across different sample periods. In the follow-up paper, Fama and French (1996) interpret their three-factor model as evidence for a 'distress premium' since it captures the performance of stock portfolios classified on size and the ratio of book-to-market value (BE/ME). Although Fama and French do not explain why 'distress risk' is priced. As the firms that have small stocks with high (BE/ME) indicates poor performance and they are vulnerable to financial distress. Various studies argue that 'distress premium' found in the Fama-French model is because of (i) survivor bias, (ii) data snooping. Brown et al. (1992) argue that elimination of stocks from the data set during the year of study naturally leads to the survivorship bias. Kothari et al. (1995) suggest that average returns on high (BE/ME) vale of portfolios are exaggerated, as 'COMPUSTAT' is more likely to add distressed firms that survive and omit the distressed firms that are less likely to survive. Using the similar set of firms for all years from 'COMPUSTAT', Breen and Korajczyk (1993) however find much weaker effect of (BE/ME) value in these data than Fama and French's findings. Moreover, the model also has difficulties in describing continuation of short-term returns or the momentum effect as documented by Jegadeesh and Titman (1993).

Jagannathan and Wang (1996) think that empirical findings against the CAPM may be because of the inappropriate assumptions that are framed to facilitate empirical analysis. In the second line of thinking, they also show that empirical evidence for the CAPM is very strong when two auxiliary assumptions are relaxed. Most empirical studies of the CAPM commonly assume that stock market index, like the FTSE All-share index, is a better substitute for the return on the market portfolio. In breakthrough article, known as 'Roll critique', Roll (1977) first pointed out the methodological problem that raised serious doubt on the validity of empirical tests of the CAPM. This critique is based on the fact that the accurate composition of the market portfolio is unknown and empirical studies only use a substitute for market portfolio which covers only a subset of assets.

Roll (1977) shows that if first pass regression is mean variance efficient while using market portfolio as proxy to estimate beta, then a perfect fit between rate of return and beta can be found in second pass regression. However, this perfect fit relationship is 'tautological' as it neither proves nor disproves the validity of CAPM. Hence, empirical studies with perfect fit is the result of using portfolio that is efficient where empirical studies with less perfect fit indicate that portfolio is not efficient. To examine whether market portfolio is effective or not, it requires to contain all assets. Since true composition of market portfolio is unknown, Roll (1977) posits that CAPM theory is untestable. Thus, a small deviation in true market portfolio can be enough to generate a poor fit between returns and betas and vice versa.

Nonetheless, one possible response to benchmark error from Jagannathan and Wang (1993) is to try to identify the omitted asset classes by adding human capital. While including human capital (the growth of labour income is used as substitute) in their measure of wealth, finding shows that it increases the CAPM's capability in explaining cross sectional differences up to $28 \%$ under the same study of Fama and French (1992). By relaxing the assumption of single period holding and allow beta to vary over time, Jagannathan and Wang (1993) also find that size has little explanatory power where the CAPM describes 57\% cross sectional differences. In response to the disputation of Fama and French (1992), Jagannathan and Wang (1993) conclude that the CAPM perform better when better proxy is used for market portfolio.

Various UK studies are conducted to examine the CAPM and the outcomes are mixed and unstable. Strong and $\mathrm{Xu}$ (1997) observe a positive association between security return and beta, though when non-market variables are added in the cross-section regression the link becomes insignificant. Furthermore, the UK studies conducted by several researchers including Strong and Xu (1997), Chan and Chui (1996) conclude that a weak association between average returns and betas is found. Therefore, empirical findings are more mixed and inconclusive.

The last half-century, the CAPM is used extensively as a standard of asset pricing models and used as an important tool for assessment of cost of capital, portfolio diversification and portfolio performance as argued by Galagedera (2007) and Shih et al. (2014). However, some firm-specific factors alongside the market beta have been documented to have significant impact on the cross-section variation in security return. Previous studies show that firm's average return is related to its size, earing to price ratio $(\mathrm{E} / \mathrm{P})$, ratio of book-to-market equity $(\mathrm{BE} / \mathrm{ME})$, leverage, cash flow to price ratio (C/P), momentum Effect and past sales growth, as documented by Banz (1981), Reinganum (1981), Basu (1983), Rosenberg et al. (1985), Bhandari (1988), Jegadeesh and Titman (1993) and Lakonishok, Shleifer and Vishny (1994). However, Carhart (1997) recommends a four-factor model in response to the shortcoming of Fama-French model in explaining all the anomalies by adding additional factors, i.e. momentum. Later Fama and French (2015) add additional variables of profitability and investment to introduce 'Five Factor Model'. 
In conclusion, empirical findings are more mixed and inconclusive. However, Dybvig and Ross (2003) argues that even though there are various modern security pricing models, Capital asset pricing model is still considered as most valuable tool that provides basic idea about the risk-return trade-off.

\section{Data and Methodology}

\subsection{Data Selection}

To investigate the validity of the CAPM during 1997-2015, monthly ending stock returns of 86 randomly selected LSE (London Stock Exchange) listed companies are chosen. Here, monthly stock returns are employed to obtain better estimates of the value of the beta coefficient. The logic behind this is that returns computed using a longer time horizon (e.g., quarterly or yearly) might result in beta changes and lead to a measurement biases in beta estimation. On the contrary, data with an intensive frequency (e.g., daily) returns might generate noisy data leading to inefficient estimation. Further, the risk-free asset is represented by the UK 1-month T-bill rate. Here, Monthly ending value of FTSE All-share index is employed as passable approximation for the study. The data used in this study is secondary in nature and has been collected from the Strathclyde Business School data server, University of Strathclyde, Glasgow, United Kingdom.

\subsection{Is FTSE All-Share Index a Passable Approximation?}

In practice, real market portfolio contains all stocks, real estate, bonds, collectibles, privately held businesses and human capital, thus all tangible and intangible assets. While arguing that the CAPM is testable, Roll (1977) and Jagannathan and Wang (1993) challenge the validity of market index as a proxy for market portfolio. The logic behind their assertion is based on the fact that tests are suffered from the non-observability of the true market portfolio. However, Kandel and Stambaugh (1995) show that OLS estimates of the CAPM have no connection with the mean-variance location of the index when market portfolio is inefficient. Interestingly Campbell et al. (1997) suggests that Roll's concern regarding mean-variance efficiency is not an empirical problem. Nonetheless, FTSE All-share index is one of the most important UK-based index. Under this index, all permitted companies have to pass screening process for their size and liquidity. FTSE All-share index is the mix of the FTSE 100, FTSE 250 and FTSE Small Cap Indices representing 98-99\% of UK market capitalization (source: FTSE Russell indexes). On the basis of the previous empirical studies as well as since FTSE All-share index represent a significant portion of the UK market, it is reasonable to use it as proxy variables. However, previous empirical results have been mixed in supporting this assumption.

\subsection{Methodology}

To test the validity of unconditional CAPM, Lintner (1965) initially suggests two steps procedure for testing the CAPM. In the first step, time series regression is applied to estimate beta coefficient of each stock and test whether CAPM holds. To estimate the beta coefficient, monthly return of each stock is regressed against the market portfolio (FTSE All-share Index). Early studies of Lintner (1965) and Black et al. (1972) employed time series technique of the CAPM using time series regressions for excess return of individual stock in relation to excess market return. The reason behind using this methodology is that this approach is one of the initial empirical tests of CAPM and has been the basis for future improvements on the CAPM over the last decades.

At first, the returns on individual stock and market index are calculated using following equations:

$$
\begin{aligned}
\mathrm{R}_{\mathrm{i}}=\mathrm{LN}\left(\frac{\mathrm{P}_{\mathrm{t}}}{\mathrm{P}_{\mathrm{t}-1}}\right) \text { Where, } R_{i} & =\text { Return on security } i . \\
P_{t} & =\text { Current price of security } i . \\
P_{t-1} & =\text { Previous price of security } i .
\end{aligned}
$$

$\mathrm{R}_{\mathrm{m}}=\mathrm{LN}\left(\frac{\mathrm{P}_{\mathrm{t}}}{\mathrm{P}_{\mathrm{t}-1}}\right)$ Where, $R_{m}=$ Return on index.

$$
\begin{aligned}
& P_{t}=\text { Current index level. } \\
& P_{t-1}=\text { Previous index level. }
\end{aligned}
$$

The next step is to run the time series regression to measure a beta $\left(\beta_{i}\right)$ for individual stocks using the monthly returns during the period. This is known as the first pass regression. The beta is estimated by regressing excess stock returns (stock returns minus risk free rates) as the dependent variable against excess market returns (market returns minus risk free rates) as the independent variable. First pass regression model is estimated as follows:

$$
R_{i t}-R_{f t}=\alpha_{0}+\beta_{i}\left(R_{m t}-R_{f t}\right)+\varepsilon_{i t}
$$


Where, $R_{i t}$ is the return on stock i, $R_{f t}$ is the risk-free rate, $\alpha_{0}$ is the regressions intercept, $R_{m t}$ is the market portfolio return, $\beta_{i}$ is the risk associated with stock $i$ and $\varepsilon_{i t}$ is the random disturbance, where, $i=1,2,3 \ldots \ldots 86$ (stocks) and $t=1,2,3 \ldots 228$ (months). The equation (1) can also be written as follows:

$$
r_{i t}=\alpha_{0}+\beta_{i} r_{m t}+\varepsilon_{i t}
$$

$$
\text { Where, } r_{i t}=R_{i t}-R_{f t} \text { and } r_{m t}=R_{m t^{-}} R_{f t}
$$

The intercept $\alpha_{0}$ (alpha) explains whether investor can gain abnormal return or he can beat the market. In the equation $\alpha_{0}$ is the difference between time series average of estimated excess return of stock and the expected return predicted by the CAPM. If the expected returns of the stock and a correct market portfolio proxy (FTSE All-share index) is selected as per CAPM describes, the regression intercepts of all stocks are zero. Thus, there is no abnormal return and investors should only be rewarded for market risk $\left(\beta_{i}\right)$. To test whether the CAPM holds or not, at first null hypothesis of intercept parameter $\alpha_{0}$ is set as zero. Now, $H_{0}^{1}$ is assigned as null hypothesis and $H_{a}^{1}$ as alternative hypothesis. That is,

$$
H_{0}^{1}: \alpha_{0}=0 \text { versus } H_{a}^{1}: \alpha_{0} \neq 0
$$

If the test fails to reject the null hypothesis, i.e., $\alpha_{0}=0$, it confirms that the CAPM holds. However, if it is not zero, the CAPM does not hold. The coefficient of estimated $\left(\beta_{i}\right)$ is used as proxy for systematic risk and the residual variance (the variance of $\sigma\left(\varepsilon_{i t}\right)$ ) is used as proxy for unsystematic risk.

Upon the computation of beta, second-pass regression (cross-sectional) is run to estimate the security market line for the testing period. At this stage, the dependent variable is the average excess stock returns, the independent variables are beta (measure of systematic risk) and residual variance (measure of unsystematic risk) for all 86 securities. The mean excess return is computed as the summation of excess return of the all stocks divided by the number of stocks during the period. The beta and the residual variance for each of the 86 shares were obtained in the first pass regression. To tests whether unsystematic risk has any impact on the expected excess return, $\sigma\left(\varepsilon_{i t}\right)$ has been included in the cross-sectional regression model:

$$
\overline{r_{l t}}=\alpha_{0}+\alpha_{1} \widehat{\beta_{l}}+\alpha_{2} \sigma\left(\varepsilon_{i t}\right)
$$

Where, $\overline{r_{l t}}=\overline{\mathrm{r}_{1}}-\overline{\mathrm{r}_{\mathrm{f}}}$ is the mean excess returns of security ' $i$ ', the coefficient $\alpha_{0}$ is the intercept, the coefficient $\alpha_{1}$ and $\alpha_{2}$ represents the effect of estimated beta $\left(\widehat{\beta}_{l}\right)$ and the variances of residual $\sigma\left(\varepsilon_{i t}\right)$ on the $\overline{r_{l t}}$. Both $\alpha_{1}$ and $\alpha_{2}$ coefficients inspect whether systematic risk (beta) and unsystematic risk $\left(\sigma\left(\varepsilon_{i t}\right)\right)$ have any influence on the average excess return of the ith stock. To examine the validity of the CAPM prediction, the second null hypothesis of coefficient $\alpha_{1}$ is set greater than zero and the third null hypothesis of coefficient $\alpha_{2}$ is set equal to zero where $\alpha_{0}$ is equal to zero as per the assumption of the CAPM. Thus, set as,

$$
\text { and } \begin{array}{lll}
H_{0}^{2}: \alpha_{1}>0 & \text { versus } & H_{a}^{2}: \alpha_{1} \leq 0 \\
H_{0}^{3}: \alpha_{2}=0 & \text { versus } & H_{a}^{3}: \alpha_{2} \neq 0
\end{array}
$$

If the coefficient $\alpha_{1}$ is greater than zero and $\alpha_{2}$ is equal to zero, it means that risk premium received due to the exposures to systematic risk and not for bearing unsystematic risk and the CAPM holds. This implies, security returns and betas are positively linearly related. The empirical testing of the CAPM has been carried out using the software package MS Excel program and EViews. To evaluate the data and regression result, t-test is conducted. To find out if the independent variables have any effect upon the dependent variable a significance level of $5 \%$ is selected. This means, $t$-statistic is considered significant if the p-value is less than 0.05 .

\section{Empirical Results of Two Stage Approach:}

\subsection{Analysis and Findings of First Pass Regression}

Given the hypothesis condition that the intercept $\left(\alpha_{0}\right)$ be not significantly different from zero, if the t-statistics is not between +1.96 and -1.96 , the null hypothesis is not accepted at $5 \%$ significance level. A perusal of the Table 1. (Appendix A) shows that only 5 stocks out of the 86 stocks illustrate intercept term with t-values higher than \pm 1.96 indicating statistical significance. However, five companies including CAPITA (2.040772>1.96), DCC (2.361080>1.96), IMPERIAL BRANDS (2.888966>1.96), RECKITT BENCKISER GROUP (2.095527>1.96) and GREGGS (2.102124515>1.96) have greater test statistics than critical value, thus reject the null hypothesis and conclude that these companies are inconsistent with the prediction of the standard CAPM. For the remaining 81 stocks the intercept term is not significant. This implies that excess stock returns are explained by the market risk premium as predicted by the CAPM. Further, when p-values of these five companies are observed at $5 \%$ significance level, confirm that null hypothesis is rejected as they are lower than 0.05 and intercept is not equal to zero. Moreover, the R-square values of each of the stock are also very low. R-square measures the variation in average excess return (as dependent variable) and exhibits that market excess return (independent variable) has 
less explanatory power.

\subsection{Analysis and Findings of Second Pass Regression}

In the second stage, the cross-section regression is conducted using betas obtained from the first pass regressions of 86 stocks to examine whether actual assets returns are cross-sectional linearly related with the actual betas. Further, unsystematic risk $\sigma\left(e_{i}\right)$ is included to examine whether beta is the only variable that explains returns of security.

Table 1. Summary result of cross sectional regression on estimated regression statistics and (ANOVA)

\begin{tabular}{c|ccccccc}
\hline & Coefficients & Standard Error & t Statistics & P-value & $\boldsymbol{R}$ Square & $\boldsymbol{F}$ & Significance $\boldsymbol{F}$ \\
\hline $\boldsymbol{\alpha}_{\mathbf{0}}$ & 0.014179 & 0.001760 & 8.055486 & 0.000000 & & & \\
$\widehat{\boldsymbol{\beta}}_{\mathbf{1}}$ & -0.004094 & 0.001259 & -3.253039 & 0.001652 & 0.348562 & 22.205187 & $1.88687 \mathrm{E}-08$ \\
$\boldsymbol{\sigma}^{\mathbf{2}}\left(\boldsymbol{\varepsilon}_{\boldsymbol{i t}}\right)$ & -0.071037 & 0.017480 & -4.063785 & 0.000109 & & & \\
\hline
\end{tabular}

Table 2 shows the result of cross-sectional regression based on the all stocks. The model (3) is employed for cross sectional analysis and the result shows that coefficient of estimated beta, $\alpha_{1}$,is negative and statistically significant. It implies that the CAPM does not specify the linear positive relationship, thus higher returns are not associated with higher risk. Thus, null hypothesis $H_{0}^{2}: \alpha_{1}>0$ is rejected at $95 \%$ confidence interval as the test statistic (-3.253039) is larger than the critical value of -1.65 obtained from t-distribution. In addition, influence of unsystematic risk on returns indicates that coefficient of variance of residuals $\sigma\left(\varepsilon_{i t}\right), \alpha_{2}$ is also negative and have significant influence. Hence, null hypothesis $H_{0}^{3}: \alpha_{2}=0$ is rejected as the test statistic (-4.063785) does not lie within +1.96 and -1.96 where the p-value $(0.000109)$ is also less than 0.05 . However, this finding contradicts the prediction of the CAPM and concludes that unsystematic risk has explanatory power and it also influences the return.

The overall result of the two-pass regression concludes that return and beta have no linear positive association. The result of the R-square is $34.86 \%$ which is very low. However, small value of R-square implies that variables $\beta$ and $\sigma\left(\varepsilon_{i t}\right)$ have very little explanatory power to explain the proportion of variation in average excess return. Moreover, Sig. F-statistics shows that all the independent variables have combined statistically significant impact on average excess return at 5\% level of significance. Thus, Sig. F-statistics less than 0.05 provide a conclusion that there is a linear interdependence between the dependent and independent variables. Due to the model misspecification and limitations in critical assumptions, various researchers have attempted to develop more generalized asset pricing model to meet the real-world situation by relaxing the assumptions. Further, multifactor models are emerged since CAPM beta alone fails to explain the cross-sectional variation in security return. In addition, another course of action is to handle the unrealistic assumptions of the CAPM by developing another asset pricing models that depends on completely different set of assumptions.

\section{Conclusion}

The empirical study inspects whether the CAPM has any explanatory power on asset pricing. This empirical study attempts to test the unconditional capital asset pricing model. Based on two pass regression model, 86 random companies are selected for the period of $1^{\text {st }}$ January 1997 to $31^{\text {st }}$ December 2015. Based on empirical results of the first pass regression, among the 86 companies, 81 companies are consistent with the prediction of the CAPM except five companies. However, the estimated R-square of 86 companies is very low and indicates that market excess return has low explanatory power. In the second pass regression, empirical result shows that beta coefficient is negative and statistically significant which implies that rate of return has no linear positive relationship with beta. Likewise, scatter graph also confirms that excess return and beta has negative relation. Further, coefficient of residual variance is also observed negative and statistically significant which violates the CAPM assumption as unsystematic risks are assumed to have no impact on rate of return. Finally, based on the regression statistics, R-square value of second pass regression is very low (34.86\%), although Sig. F-statistics shows that all the independent variables have combined statistically significant impact on average excess return. In conclusion, CAPM predictions are not consistent with the findings of this study; hence the CAPM is violated and does not hold.

\section{References}

Amihud, Y., Christensen, B. J., \& Mendelson, H. (1992). Further evidence on the risk-return relationship (No. 1248). Graduate School of Business, Stanford University. Retrieved from http://efinance.org.cn/cn/fm/Further\%20evidence\%20on\%20the\%20risk-return\%20relationship.pdf 
Banz, R. W. (1981). The relationship between return and market value of common stocks. Journal of Financial Economics, 9(1), 3-18. https://doi.org/10.1016/0304-405X(81)90018-0

Basu, S. (1977). Investment performance of common stocks in relation to their price-earnings ratios: A test of the efficient market hypothesis. The Journal of Finance, 32(3), 663-682. https://doi.org/10.1111/j.1540-6261.1977.tb01979.x

Basu, S. (1983). The relationship between earnings' yield, market value and return for NYSE common stocks: Further evidence. Journal of Financial Economics, 12(1), 129-156. https://doi.org/10.1016/0304-405X(83)90031-4

Bhandari, L. C. (1988). Debt/equity ratio and expected common stock returns: Empirical evidence. The Journal of Finance, 43(2), 507-528. https://doi.org/10.1111/j.1540-6261.1988.tb03952.x

Black, F. (1972). Capital market equilibrium with restricted borrowing. The Journal of Business, 45(3), 444-455. https://doi.org/10.1086/295472

Black, F. (1993). Beta and return. The Journal of Portfolio Management, 20(1), 8-18. https://doi.org/10.3905/jpm.1993.409462

Black, F., Jensen, M. C., \& Scholes, M. (1972). The Capital Asset Pricing Model: Some Empirical Tests'. In M Jensen (Ed.), Studies in the theory of capital markets. Praeger Publisher. Retrieved from http://papers.ssrn.com/sol3/papers.cfm?abstract_id=908569

Breeden, D. T. (1979). An intertemporal asset pricing model with stochastic consumption and investment $\begin{array}{lllll}\text { opportunities. Journal of } & \text { Financial }\end{array}$ https://doi.org/10.1016/0304-405X(79)90016-3

Breen, W. J., \& Korajczyk, R. A. (1993). On selection biases in book-to-market based tests of asset pricing models. Northwestern Universi\& Workingpaper, 167. Retrieved from http://www.kellogg.northwestern.edu/faculty/korajczy/htm/wp167.pdf

Brennan, M. J., Wang, A. W., \& Xia, Y. (2004). Estimation and test of a simple model of intertemporal capital asset pricing. The Journal of Finance, 59(4), 1743-1776. https://doi.org/10.1111/j.1540-6261.2004.00678.x

Brown, S. J., Goetzmann, W., Ibbotson, R. G., \& Ross, S. A. (1992). Survivorship bias in performance studies. Review of Financial Studies, 5(4), 553-580. https://doi.org/10.1093/rfs/5.4.553

Campbell, J. Y., Lo, A. W. C., \& MacKinlay, A. C. (1997). The econometrics of financial markets (Vol. 2, pp. 149-180). Princeton, NJ: Princeton University press.

Carhart, M. M. (1997). On persistence in mutual fund performance. The Journal of finance, 52(1), 57-82. https://doi.org/10.1111/j.1540-6261.1997.tb03808.x

Chan, A., \& Chui, A. P. (1996). An Empirical Re - Examination of the Cross-Section of Expected Returns: UK Evidence. Journal of Business Finance \& Accounting, 23(9-10), 1435-1452. https://doi.org/10.1111/j.1468-5957.1996.tb01211.x

Chan, L. K., Hamao, Y., \& Lakonishok, J. (1991). Fundamentals and stock returns in Japan. The Journal of Finance, 46(5), 1739-1764. https://doi.org/10.1111/j.1540-6261.1991.tb04642.x

Chen, N. F., Roll, R., \& Ross, S. A. (1986). Economic forces and the stock market. Journal of Business, 383-403. https://doi.org/10.1086/296344

Cochrane, J. (2001). Asset pricing. Princeton, NJ: Princeton University Press.

Douglas, G. W. (1969). Risk in the Equity Markets: An Empirical Appraisal of Market Efficiency. Yale Economic Essays, $\quad I X, \quad 3-45 . \quad$ Retrieved from https://www.researchgate.net/publication/35605165_Risk_in_the_equity_markets_An_empirical_appraisal_ of_market_efficiency

Dybvig, P. H., \& Ross, S. A. (2003). Arbitrage, state prices and portfolio theory. Handbook of the Economics of Finance, 1, 605-637. https://doi.org/10.1016/S1574-0102(03)01019-7

Fama, E. F. (1991). Efficient capital markets: II. The Journal of Finance, 46(5), 1575-1617. https://doi.org/10.1111/j.1540-6261.1991.tb04636.x

Fama, E. F., \& French, K. R. (1992). The cross-section of expected stock returns. The Journal of Finance, 47(2), 427-465. https://doi.org/10.1111/j.1540-6261.1992.tb04398.x 
Fama, E. F., \& French, K. R. (1993). Common risk factors in the returns on stocks and bonds. Journal of Financial Economics, 33(1), 3-56. https://doi.org/10.1016/0304-405X(93)90023-5

Fama, E. F., \& French, K. R. (1995). Size and book-to-market factors in earnings and returns. The Journal of Finance, 50(1), 131-155. https://doi.org/10.1111/j.1540-6261.1995.tb05169.x

Fama, E. F., \& French, K. R. (1996). Multifactor explanations of asset pricing anomalies. The Journal of Finance, 51(1), 55-84. https://doi.org/10.1111/j.1540-6261.1996.tb05202.x

Fama, E. F., \& French, K. R. (2015). A five-factor asset pricing model. Journal of Financial Economic, 116, 1-22. https://doi.org/10.1016/j.jfineco.2014.10.010

Fama, E. F., \& MacBeth, J. D. (1973). Risk, return, and equilibrium: Empirical tests. The Journal of Political Economy, 607-636. https://doi.org/10.1086/260061

Galagedera, D. U. (2007). A review of capital asset pricing models. Managerial Finance, 33(10), 821-832. https://doi.org/10.1108/03074350710779269

Groenewold Fraser, N. (1997). Share prices and macroeconomic factors. Journal of Business Finance \& Accounting, 24(9-10), 1367-1383. https://doi.org/10.1111/1468-5957.t01-1-00168

Horowitz, J. L., Loughran, T., \& Savin, N. E. (2000). Three analyses of the firm size premium. Journal of Empirical Finance, 7(2), 143-153. https://doi.org/10.1016/S0927-5398(00)00008-6

Jagannathan, R., \& McGrattan, E. R. (1995). The CAPM debate. Federal Reserve Bank of Minneapolis. Quarterly Review-Federal Reserve Bank of Minneapolis, 19(4), 2. Retrieved from http://kczx.shupl.edu.cn/download/06f8b0b0-22d1-4290-9e09-888351d3df0d.pdf

Jagannathan, R., \& Wang, Z. (1996). The conditional CAPM and the cross-section of expected returns. The Journal of Finance, 51(1), 3-53. https://doi.org/10.1111/j.1540-6261.1996.tb05201.x

Jegadeesh, N., \& Titman, S. (1993). Returns to buying winners and selling losers: Implications for stock market efficiency. The Journal of Finance, 48(1), 65-91. https://doi.org/10.1111/j.1540-6261.1993.tb04702.x

Kandel, S., \& Stambaugh, R. F. (1995). Portfolio Inefficiency and the Cross-section of Expected Returns. The Journal of Finance, 50(1), 157-184. https://doi.org/10.1111/j.1540-6261.1995.tb05170.x

Kothari, S. P., Shanken, J., \& Sloan, R. G. (1995). Another look at the cross-section of expected stock returns. The Journal of Finance, 50(1), 185-224. https://doi.org/10.1111/j.1540-6261.1995.tb05171.x

Lakonishok, J., Shleifer, A., \& Vishny, R. W. (1994). Contrarian investment, extrapolation, and risk. The Journal of Finance, 49(5), 1541-1578. https://doi.org/10.1111/j.1540-6261.1994.tb04772.x

Levhari, D., \& Levy, H. (1977). The capital asset pricing model and the investment horizon. The Review of Economics and Statistics, 92-104. https://doi.org/10.2307/1924908

Levy, H. (1978). Equilibrium in an Imperfect Market: A Constraint on the Number of Securities in the Portfolio. The American Economic Review, 68(4), 643-658. Retrieved from http://www.jstor.org/stable/1808932

Lintner, J. (1965). Security prices and risk: The theory and comparative analysis of AT \&T. and leading industrials. In conference on "The Economics of Regulated Public Utilities" at the University of Chicago Business School.

Lintner, J. (1965). Security prices, risk, and maximal gains from diversification. The Journal of Finance, 20(4), 587-615. https://doi.org/10.1111/j.1540-6261.1965.tb02930.x

Markowitz, H. (1952). Portfolio selection. The Journal of Finance, 7(1), 77-91. https://doi.org/10.1111/j.1540-6261.1952.tb01525.x

Merton, R. C. (1973). An intertemporal capital asset pricing model. Econometrica: Journal of the Econometric Society, 867-887. https://doi.org/10.2307/1913811

Miller, M. H., \& Scholes, M. (1972). Rates of return in relation to risk: A reexamination of some recent findings. Studies in the Theory of Capital Markets, 23. Retrieved from https://www.econbiz.de/Record/rates-of-return-in-relation-to-risk-a-re-examination-of-some-recent-findings -miller-merton/10002493316

Mossin, J. (1966). Equilibrium in a Capital Asset Market. Econometrica, 34(4), 768-783. https://doi.org/10.2307/1910098

Reinganum, M. R. (1981). Misspecification of capital asset pricing: Empirical anomalies based on earnings' 
yields and market values. Journal of financial Economics, 9(1), 19-46. https://doi.org/10.1016/0304-405X(81)90019-2

Roll, R. (1977). A critique of the asset pricing theory's tests Part I: On past and potential testability of the theory. Journal of Financial Economics, 4(2), 129-176. https://doi.org/10.1016/0304-405X(77)90009-5

Roll, R., \& Ross, S. A. (1984). A critical reexamination of the empirical evidence on the arbitrage pricing theory: A reply. The Journal of Finance, 39(2), 347-350. https://doi.org/10.1111/j.1540-6261.1984.tb02313.x

Roll, R., \& Ross, S. A. (1994). On the cross-sectional relation between expected returns and betas. The Journal of Finance, 49(1), 101-121. https://doi.org/10.1111/j.1540-6261.1994.tb04422.x

Rosenberg, B., Reid, K., \& Lanstein, R. (1985). Persuasive evidence of market inefficiency. The Journal of Portfolio Management, 11(3), 9-16. https://doi.org/10.3905/jpm.1985.409007

Ross, S. A. (1976). The arbitrage theory of capital asset pricing. Journal of Economic Theory, 13(3), 341-360. https://doi.org/10.1016/0022-0531(76)90046-6

Sharifzadeh, M. (2010). An Empirical and Theoretical Analysis of Capital Asset Pricing Model. Universal-Publishers.

Sharpe, W. F. (1964). Capital asset prices: A theory of market equilibrium under conditions of risk. The Journal of Finance, 19(3), 425-442. https://doi.org/10.1111/j.1540-6261.1964.tb02865.x

Shih, Y. C., Chen, S. S., Lee, C. F., \& Chen, P. J. (2014). The evolution of capital asset pricing models. Review of Quantitative Finance and Accounting, 42(3), 415-448. https://doi.org/10.1007/s11156-013-0348-x

Stattman, D. (1980). Book values and stock returns. The Chicago MBA: A Journal of Selected Papers, 4(1), $25-45$.

Strong, N., \& Xu, X. G. (1997). Explaining the cross-section of UK expected stock returns. The British Accounting Review, 29(1), 1-23. https://doi.org/10.1006/bare.1996.0030

Tobin, J. (1958). Liquidity preference as behavior towards risk. The Review of Economic Studies, 25(2), 65-86. https://doi.org/10.2307/2296205

\section{Appendix A}

Summary result of first pass time-series regression

\begin{tabular}{|c|c|c|c|c|c|c|c|c|c|}
\hline No. & Name & & $t$-statistics & P-value & No. & Name & & $t$-statistics & $P$-value \\
\hline 01. & PHOTO-ME INTL. & $\begin{array}{c}\alpha_{0} \\
\beta\end{array}$ & $\begin{array}{l}0.515530 \\
0.56544\end{array}$ & 0.6066866 & 44. & HAYS & $\begin{array}{c}\alpha_{0} \\
\beta\end{array}$ & $\begin{array}{l}-0.377800612 \\
1.18451\end{array}$ & 0.705933299 \\
\hline 02. & ANGLO AMERICAN & $\begin{array}{c}\alpha_{0} \\
\beta\end{array}$ & $\begin{array}{l}-1.543510 \\
1.67903\end{array}$ & 0.1241062 & 45. & ST. IVES & $\begin{array}{c}\alpha_{0} \\
\beta\end{array}$ & $\begin{array}{l}-0.718275311 \\
1.23593\end{array}$ & 0.473329434 \\
\hline 03. & $\begin{array}{l}\text { SPIRAX-SARCO } \\
\text { ENGR. }\end{array}$ & $\begin{array}{c}\alpha_{0} \\
\beta\end{array}$ & $\begin{array}{l}1.063932 \\
0.98327\end{array}$ & 0.2884948 & 46. & PENDRAGON & $\begin{array}{c}\alpha_{0} \\
\beta\end{array}$ & $\begin{array}{l}0.1264647 \\
1.18972\end{array}$ & 0.899477 \\
\hline 04. & CAPITA & $\begin{array}{c}\alpha_{0} \\
\beta\end{array}$ & $\begin{array}{l}2.040772 \\
0.81906\end{array}$ & 0.0424359 & 47. & PREMIER FARNELL & $\begin{array}{c}\alpha_{0} \\
\beta\end{array}$ & $\begin{array}{l}-1.687596 \\
1.53480\end{array}$ & 0.0928685 \\
\hline 05. & AVON RUBBER & $\begin{array}{c}\alpha_{0} \\
\beta\end{array}$ & $\begin{array}{l}-0.125316 \\
1.04002\end{array}$ & 0.9003849 & 48. & BODYCOTE & $\begin{array}{c}\alpha_{0} \\
\beta\end{array}$ & $\begin{array}{l}-0.090570446 \\
1.60355\end{array}$ & 0.927914136 \\
\hline 06. & RPC GROUP & $\begin{array}{c}\alpha_{0} \\
\beta\end{array}$ & $\begin{array}{l}1.530401 \\
0.74454\end{array}$ & 0.1273160 & 49. & WIRELESS GROUP & $\begin{array}{c}\alpha_{0} \\
\beta\end{array}$ & $\begin{array}{l}-0.156812156 \\
1.00896\end{array}$ & 0.875532888 \\
\hline 07. & ATKINS (WS) & $\begin{array}{c}\alpha_{0} \\
\beta\end{array}$ & $\begin{array}{l}0.295932 \\
1.40432\end{array}$ & 0.7675540 & 50. & $\begin{array}{l}\text { ROLLS-ROYCE } \\
\text { HOLDINGS }\end{array}$ & $\begin{array}{c}\alpha_{0} \\
\beta\end{array}$ & $\begin{array}{l}0.124954836 \\
1.32056\end{array}$ & 0.900670381 \\
\hline 08. & MCBRIDE & $\begin{array}{c}\alpha_{0} \\
\beta\end{array}$ & $\begin{array}{l}0.038830 \\
0.65854\end{array}$ & 0.9690604 & 51. & STV GROUP & $\begin{array}{c}\alpha_{0} \\
\beta\end{array}$ & $\begin{array}{l}-1.155562325 \\
1.018639335\end{array}$ & 0.249080437 \\
\hline 09. & MEGGITT & $\begin{array}{c}\alpha_{0} \\
\beta\end{array}$ & $\begin{array}{l}0.803317 \\
1.28396\end{array}$ & 0.4226358 & 52. & SKY & $\begin{array}{c}\alpha_{0} \\
\beta\end{array}$ & $\begin{array}{l}0.141162743 \\
0.652770643\end{array}$ & 0.887867123 \\
\hline 10. & SYNTHOMER & $\begin{array}{c}\alpha_{0} \\
\beta\end{array}$ & $\begin{array}{l}-0.077177 \\
0.96202\end{array}$ & 0.9385507 & 53. & MARSHALLS & $\begin{array}{c}\alpha_{0} \\
\beta\end{array}$ & $\begin{array}{l}0.513075434 \\
1.120983219\end{array}$ & 0.608399714 \\
\hline 11. & HALMA & $\begin{array}{c}\alpha_{0} \\
\beta\end{array}$ & $\begin{array}{l}1.404215 \\
0.80755\end{array}$ & 0.1616277 & 54. & WH SMITH & $\begin{array}{c}\alpha_{0} \\
\beta\end{array}$ & $\begin{array}{l}1.175959372 \\
0.892245467\end{array}$ & 0.240848371 \\
\hline 12. & PEARSON & $\begin{array}{c}\alpha_{0} \\
\beta\end{array}$ & $\begin{array}{l}-0.384371 \\
1.03498\end{array}$ & 0.7010646 & 55. & 4IMPRINT GROUP & $\begin{array}{c}\alpha_{0} \\
\beta\end{array}$ & $\begin{array}{l}0.367839331 \\
1.140385655\end{array}$ & 0.713337304 \\
\hline
\end{tabular}




\begin{tabular}{|c|c|c|c|c|c|c|c|c|c|}
\hline \multirow[t]{2}{*}{13.} & EUROMONEY & $\alpha_{0}$ & 0.369712 & 0.7119433 & 56. & GALLIFORD TRY & $\alpha_{0}$ & 1.541489101 & 0.124596795 \\
\hline & INSTL.INVESTOR & $\beta$ & 1.10980 & & & & $\beta$ & 0.879908767 & \\
\hline \multirow[t]{2}{*}{14.} & CHEMRING GROUP & $\alpha_{0}$ & 0.479144 & 0.6322994 & 57. & MARSTON'S & $\alpha_{0}$ & 0.193014376 & 0.847121054 \\
\hline & & $\beta$ & 0.47379 & & & & $\beta$ & 0.898748263 & \\
\hline \multirow[t]{2}{*}{15.} & COSTAIN GROUP & $\alpha_{0}$ & -0.467263 & 0.6407617 & 58. & ACAL & $\alpha_{0}$ & -0.3035592 & 0.761743011 \\
\hline & & $\beta$ & 0.83011 & & & & $\beta$ & 0.905179795 & \\
\hline \multirow[t]{2}{*}{16.} & GAMES WORKSHOP & $\alpha_{0}$ & 0.014266 & 0.9886307 & 59. & JOHNSTON PRESS & $\alpha_{0}$ & -1.825705631 & 0.069214269 \\
\hline & & $\beta$ & 0.41689 & & & & $\beta$ & 1.821698264 & \\
\hline \multirow[t]{2}{*}{17.} & LAVENDON GROUP & $\alpha_{0}$ & -0.371293471 & 0.710766794 & 60. & MENZIES (JOHN) & $\alpha_{0}$ & -0.389444486 & 0.697314091 \\
\hline & & $\beta$ & 1.73108 & & & & $\beta$ & 1.023815562 & \\
\hline \multirow[t]{2}{*}{18.} & SERCO GROUP & $\alpha_{0}$ & -0.675873628 & 0.4998119 & 61. & COMMUNISIS & $\alpha_{0}$ & -0.579058032 & 0.563126706 \\
\hline & & $\beta$ & 1.03406 & & & & $\beta$ & 0.767283164 & \\
\hline \multirow[t]{2}{*}{19.} & DIAGEO & $\alpha_{0}$ & 1.513020099 & 0.131671695 & 62. & IMAGINATION TECH & $\alpha_{0}$ & -0.192338574 & 0.847649721 \\
\hline & & $\beta$ & 0.57460 & & & & $\beta$ & 1.743946411 & \\
\hline \multirow[t]{2}{*}{20.} & OXFORD BIOMEDICA & $\alpha_{0}$ & -1.059246832 & 0.290618159 & 63. & ASSOCIATED & $\alpha_{0}$ & 1.572093974 & 0.117327674 \\
\hline & & $\beta$ & 0.92688 & & & BRIT.FOODS & $\beta$ & 0.536278044 & \\
\hline \multirow[t]{2}{*}{21.} & FENNER & $\alpha_{0}$ & -0.273580893 & 0.784656578 & 64. & DIPLOMA & $\alpha_{0}$ & 1.846793769 & 0.066084378 \\
\hline & & $\beta$ & 1.17025 & & & & $\beta$ & 0.670307161 & \\
\hline \multirow[t]{2}{*}{22.} & DCC & $\alpha_{0}$ & 2.361080424 & 0.019071906 & 65. & VICTREX & $\alpha_{0}$ & 1.002703998 & 0.317076068 \\
\hline & & $\beta$ & 0.95471 & & & & $\beta$ & 0.910094214 & \\
\hline \multirow[t]{2}{*}{23.} & TRIFAST & $\alpha_{0}$ & -0.314180293 & 0.753673936 & 66. & BOOT (HENRY) & $\alpha_{0}$ & 1.059726306 & 0.290400386 \\
\hline & & $\beta$ & 0.99961 & & & & $\beta$ & 0.760871045 & \\
\hline \multirow[t]{2}{*}{24.} & RIO TINTO & $\alpha_{0}$ & 0.085879199 & 0.931638481 & 67. & ITV & $\alpha_{0}$ & -0.384518927 & 0.700955445 \\
\hline & & $\beta$ & 1.55534 & & & & $\beta$ & 1.694311886 & \\
\hline \multirow[t]{2}{*}{25.} & LADBROKES & $\alpha_{0}$ & -0.836691373 & 0.403649891 & 68. & ELECTROCOMP. & $\alpha_{0}$ & -0.874960799 & 0.382524134 \\
\hline & & $\beta$ & 1.11217 & & & & $\beta$ & 1.241872314 & \\
\hline \multirow[t]{2}{*}{26.} & KIER GROUP & $\alpha_{0}$ & 1.529786941 & 0.127467939 & 69. & G4S & $\alpha_{0}$ & 0.736510317 & 0.46218401 \\
\hline & & $\beta$ & 0.85078 & & & & $\beta$ & 0.796371759 & \\
\hline \multirow[t]{2}{*}{27.} & NATIONAL EXPRESS & $\alpha_{0}$ & -0.21263005 & 0.831807191 & 70. & HEADLAM GROUP & $\alpha_{0}$ & 0.324802826 & 0.74563076 \\
\hline & & $\beta$ & 1.08608 & & & & $\beta$ & 0.715753682 & \\
\hline 28. & HO ME RETAI L & $\alpha_{0}$ & -0.934983777 & 0.350794522 & 71. & FULLER SMITH \& & $\alpha_{0}$ & 1.665374799 & 0.097223568 \\
\hline & GROUP & $\beta$ & 0.87962 & & & TURNR.'A' & $\beta$ & 0.478417186 & \\
\hline 29. & GOODWIN & $\alpha_{0}$ & 1.600702813 & 0.110839655 & 72. & BALFOUR BEATTY & $\alpha_{0}$ & -0.129606518 & 0.896993023 \\
\hline & & $\beta$ & 0.49836 & & & & $\beta$ & 0.897668592 & \\
\hline 30. & GKN & $\alpha_{0}$ & -0.162130694 & 0.871347797 & 73. & BLOOMSBURY PBL. & $\alpha_{0}$ & 1.104108779 & 0.270720119 \\
\hline & & $\beta$ & 1.72537 & & & & $\beta$ & 0.447883228 & \\
\hline 31. & RANK GROUP & $\alpha_{0}$ & -0.5114523 & 0.60952211 & 74. & VESUVIUS & $\alpha_{0}$ & -1.518167554 & 0.130369781 \\
\hline & & $\beta$ & 0.83795 & & & & $\beta$ & 2.748425384 & \\
\hline 32. & IMPERIAL BRANDS & $\alpha_{0}$ & 2.888965622 & 0.004240973 & 75. & WOLSELEY & $\alpha_{0}$ & -0.202729803 & 0.839528621 \\
\hline & & $\beta$ & 0.34951 & & & & $\beta$ & 1.542227938 & \\
\hline 33. & ENTERPRISE INNS & $\alpha_{0}$ & 0.010198676 & 0.991871772 & 76. & STAGECOACH & $\alpha_{0}$ & 0.124715554 & 0.900859603 \\
\hline & & $\beta$ & 1.43465 & & & GROUP & $\beta$ & 0.962205746 & \\
\hline 34. & PERSIMMON & $\alpha_{0}$ & 1.2025749 & 0.23039478 & 77. & GREGGS & $\alpha_{0}$ & 2.102124515 & 0.036649498 \\
\hline & & $\beta$ & 1.02621 & & & & $\beta$ & 0.409018624 & \\
\hline 35. & SIG & $\alpha_{0}$ & -0.708366338 & 0.479447765 & 78. & CARR'S GROUP & $\alpha_{0}$ & 1.160662077 & 0.24700389 \\
\hline & & $\beta$ & 1.52388 & & & & $\beta$ & 0.679171243 & \\
\hline 36. & SEVERFIELD & $\alpha_{0}$ & 0.08620109 & 0.931382885 & 79. & BROWN (N) GROUP & $\alpha_{0}$ & -0.0580297 & 0.953776247 \\
\hline & & $\beta$ & 0.82795 & & & & $\beta$ & 0.871492496 & \\
\hline 37. & CRODA & $\alpha_{0}$ & 1.4514046 & 0.1480540 & 80. & ANGLO-EASTERN & $\alpha_{0}$ & 0.874840974 & 0.382589197 \\
\hline & INTERNATIONAL & $\beta$ & 0.92029 & & & PLTNS. & $\beta$ & 0.603632996 & \\
\hline 38. & VITEC GROUP & $\alpha_{0}$ & -0.355603486 & 0.722469217 & 81. & GREENCORE GROUP & $\alpha_{0}$ & -0.133277356 & 0.894092632 \\
\hline & & $\beta$ & 1.01775 & & & & $\beta$ & 1.226032476 & \\
\hline 39. & RECKITT BENCKISER & $\alpha_{0}$ & 2.095526885 & 0.037237411 & 82. & СОВНАМ & $\alpha_{0}$ & 0.899085179 & 0.36956422 \\
\hline & GROUP & $\beta$ & 0.44321 & & & & $\beta$ & 0.825094795 & \\
\hline 40. & GLAXOSMITHKLINE & $\alpha_{0}$ & 0.256403521 & 0.797872518 & 83. & SHANKS GROUP & $\alpha_{0}$ & -0.496123428 & 0.620289481 \\
\hline & & $\beta$ & 0.53930 & & & & $\beta$ & 1.189686396 & \\
\hline 41. & SAGE GROUP & $\alpha_{0}$ & 1.076700498 & 0.282762081 & 84. & GREENE KING & $\alpha_{0}$ & 0.995591195 & 0.320513575 \\
\hline & & $\beta$ & 1.33799 & & & & $\beta$ & 0.706090738 & \\
\hline 42. & BRAMMER & $\alpha_{0}$ & -0.681441351 & 0.496289944 & 85. & OXFORD & $\alpha_{0}$ & 0.11540301 & 0.908228164 \\
\hline
\end{tabular}




\begin{tabular}{|c|c|c|c|c|c|c|c|c|c|}
\hline \multirow{3}{*}{43.} & & $\beta$ & 0.92251 & & & INSTRUMENTS & $\beta$ & 0.937537881 & \\
\hline & NORTHGATE & $\alpha_{0}$ & -0.811252 & 0.4180750 & 86. & CAPE & $\alpha_{0}$ & -0.340329841 & 0.733924267 \\
\hline & & $\beta$ & 1.56472 & & & & $\beta$ & 2.199862393 & \\
\hline
\end{tabular}

\section{Copyrights}

Copyright for this article is retained by the author(s), with first publication rights granted to the journal.

This is an open-access article distributed under the terms and conditions of the Creative Commons Attribution license (http://creativecommons.org/licenses/by/4.0/). 